\title{
УКРАЇНСЬКО-АМЕРИКАНСЬКІ ВІДНОСИНИ В ГАЛУЗІ КІНО: СУЧАСНИЙ СТАН
}

У статті досліджуються особливості українсько-американських відносин у галузі кіно, а також розглянуто різні форми взаємодї кінематографій двох країн на сучасному етапі розвитку.

Ключові слова: украйнський кінематограф, американський кінематограф, Голлівуд, украйнсько-американські відносини.

В статье исследуются особенности украинско-американских отношений в сфере кино, а также рассмотрены разные формы взаимодействия кинематографий двух стран на современном этапе развития.

Ключевые слова: украинский кинематограф, американский кинематограф, Голливуд, украинско-американские отношения.

The features of Ukraine-United States relations in the field of cinema are explored in the article, also various forms of cinematographies interaction of two countries at the present stage of development are considered.

Keywords: Ukrainian cinema, American cinema, Hollywood, Ukraine-United States relations.

Процес розвитку дружніх відносин між Україною та США має тривалу історію. І останнім часом рівень співробітництва між двома державами в усіх галузях, в тому числі в кінематографії, значно зміцнився. Національний кінематограф кожної країни $\epsilon$ уособленням певних культурних ознак своєї нації, має індивідуальні особливості та виражає, так би мовити, національну ідентичність країни. Досить частим явищем в сучасному глобалізованому світі стає певний діалог і перетин культур або ж, у нашому випадку, — запозичення у провідних світових фільмовиробництв вдалих кінематографічних надбань.

Початок нового тисячоліття відзначився посиленням глобалізаційних процесів у світі, що торкнулися кінематографа, в межах яких США як лідер у цій галузі транслює і ділиться своїми здобутками з іншими країнами. Адже впродовж усього часу існування кінематографа американське кіно, зокрема голлівудське, завдяки своєму неосяжному досвіду в кіновиробничій справі, видовищності стрічок та прихильності публіки, уособлювало в собі взірець наслідування для розвитку кінематографії в кожній країні, особливо у питаннях виробництва жанрового та комерційного кіно.
Кінематографічні зв'язки між країнами можуть розвиватися в напрямах закупівлі одна у одної фільмів, запозичення кінематографічних надбань, під час створення копродукції, наданні-отриманні грантів, при стажуванні кіновиробників або на базі фестивальних взаємодій. Оскільки кінематограф Сполучених Штатів $\epsilon$ значно потужнішим за український, то відповідно займає більш активну позицію в обміні кінематографічними здобутками з Україною.

Питання взаємодії Сполучених Штатів і України в межах кіногалузі $є$ маловивченим, деяких аспектів цієї теми торкалися в своїх працях українські дослідники Л. Брюховецька, І. Зубавіна, В. Ілляшенко, О. Мусієнко, Н. Мусієнко, М. Юдов, К. Данилишина та інші.

У галузі кіно українсько-американські відносини будуються здебільшого на основі запозичення кінематографічних надбань та імпорту фільмів із Голлівуду. Ні для кого не секрет, що Голлівуд виступає транслятором художніх стандартів.

Вперше кінематографічні взаємозв'язки 3 американськими колегами було налагоджено на початку XX ст. Уже до 1914 року остаточно сформувалася система кінопрокату. Так, наприклад, в Одесі була заснована прокатна контора, «М. Зу- 
сман и Я. А. Корн», що спеціалізувалась на прокаті американських фільмів $[1,12]$.

У радянські часи поширення американського кіно продовжувалось. А в програмах кінопоказів зазначалися не лише документальні та пропагандистські фільми, а й голлівудське комерційне кіно. Свого часу Всеукраїнське фотокіноуправління (ВУФКУ) підписало угоди зі співробітництва 3 американськими кіностудіями щодо постачання кінообладнання, плівки та готової продукції. А 3 боку українського кінематографа, починаючи 3 1929 року, ВУФКУ експортувало до США перші свої великі фільми.

Особливо помітним поширення американського кіно було у 1942 році, коли оголосили «культурну відкритість», проте закон все ще забороняв контакти 3 іноземцями. Про це говорить російська дослідниця І. Антонова, яка вивчала радянсько-американські відносини в галузі кіно. За іï словами, Сталін був великим поціновувачем голлівудських фільмів і вибірково дозволяв радянським режисерам знайомитися з американськими стрічками для того, щоб вони в своїх працях наслідували американське кіно $з$ його «хеппі-ендами» та іншими елементами, які могли б слугувати інструментами внутрішньої пропаганди [2]. Тому, вважає дослідниця, радянські фільми перебували під значним впливом американського кінематографа, що відобразилось у запозиченні художніх образів та прийомів зйомки.

Після підняття «залізної завіси» наприкінці 1980-х років обмін кінематографічними здобутками між Україною та США став відбуватися вільно й активно. На тлі зламу радянської ідеології та збільшення відкритості меж для експорту американської кінопродукції на українському екрані з'являються не лише суто голлівудські стрічки, а й створюються вітчизняні, які демонструють американські цінності та спосіб життя. Так, можна згадати кінострічку українського режисера О. Iсаєва «Путана», котру зафільмували в перший рік незалежності країни. Вивіски англійською, долари, одяг і побутові речі американських брендів, американські пісні, показ вживання алкоголю, тютюнових виробів і проституції, які були досить обмеженими свого часу на радянському екрані, неодноразово з'являються в кадрі.

Щодо імпорту голлівудських стрічок в Україну ситуація складається доволі прозоро, адже із року в рік левову частку репертуару українських кінотеатрів становить власне голлівудська продукція. Інше питання - щодо використання голлівудських стандартів кіновиробництва у процесі створення українських фільмів. Причини такого звернення до зарубіжного досвіду можуть бути різними: це - i пошук продюсерів та режисерів нових, але насправді добре відомих моделей кіновиробництва через наявність слабких сторін вітчизняної кіноіндустрії, і спроба відійти від радянського минулого та російського кіно, і задоволення потреб глядацької аудиторії, i просто рівняння на світового лідера кінематографії та переймання справді якісних технологій кіновиробництва тощо. Так, російська культуролог Г. Трепакова зауважує: важливим фактором $€$ власне видовищно-технічний бік американських фільмів, що додає їм такої популярності [3, 14]. За часів української незалежності проблемним стало питання змістовного наповнення фільмів, простежувалася традиція відходу кіновиробництва від сфери споживання. Сьогодні українські кінематографісти поступово почали орієнтуватися на виконання соціокультурних запитів глядацької аудиторії.

Впливу від американської кінематографії 3 iї високим рівнем і здобутками різною мірою зазнало багато сучасних українських ігрових фільмів майже на кожній структурній ланці кінематографічного процесу, від художника до глядача. Українські режисери неодноразово звертались до голлівудських технологій фільмовиробництва, запозичуючи в деяких моментах тематику, жанрове вирішення, сюжетні лінії, художні образи та художнє вирішення з декораціями і одягом, технічні здобутки, графіку, монтаж, музику, принципи продюсуваня та дистрибуції і навіть елементи американської культури. Проте український кінознавець М. Юдов робить висновки, що « $<\ldots>$ вітчизняний ринок являє собою досить невдале сліпе копіювання американських стандартів художньої архітектоніки фільмів» $[4,95]$.

Розглядаючи жанрове розмаїття сучасних українських фільмів, можна побачити, що останнім часом дедалі частіше почали з'являтися такі нетипові для вітчизняного кінематографа жанри та вкраплення елементів цих жанрів, як: хорор, гангстерські фільми, нуар, екшн, трилери, еродрами.

Голлівудська кіноіндустрія є одним із наймасштабніших виробників кінопродукції у жанрі хорор, або фільмів жахів, хоча запозичили американці цю ідею у Свропи, насамперед у Німеччини, у період «великої депресії». Сьогодні українські кінематографісти намагаються відтворити цей жанр на вітчизняних кіноекранах. Прикладом цьому є стрічка «Синевир» режисерів Олександра 
і В'ячеслава Альошечкіних та трешовий фільм жахів «Шлях мерця» Георгія Фоміна.

Відповідає жанровим вимогам гангстерського фільму кінострічка Любомира Левицького «Ломбард», в основі якої лежить типова для американських фільмів історія пограбування банку. Формальний натяк на зарубіжне кіно має і фільм Клима Козинського «Найбільший теніс», у якому простежується спроба створення кримінального фільму у стилі Гая Річі чи навіть Квентіна Тарантіно з елементами мальованої під комікс графіки.

Суто американським є жанр «нуар», нотки якого, на думку кінокритиків, наявні у фільмі Мирослава Слабошпицького «Плем'я».

Жанр «бойовик», або «екшн», знайшов своє втілення в таких українських кінофільмах, як «Вихід» режисера Ігоря Копилова, «Прорвемось» Івана Кривчишина та інших.

Популярним голлівудським жанром, який побутує в українському кінопросторі як у чистому вигляді, так і у трансформованому, є трилер. Показові стрічки, виконані у цьому жанрі, це - «Ілюзія страху» Олександра Кірієнка, «Таємничий острів» $\mathrm{i}$ «Зелена кофта» Володимира Тихого тощо.

Також слід зазначити, що українські кінематографісти останнім часом не нехтують жанром еродрами, якого за радянських часів на вітчизняних екранах бути не могло, але котрий не була заборонений Штатах. Прикладами сучасної української еродрами можна назвати стрічку Роберта Кромбі «Сафо» та короткометражний фільм Олега Борщевського «Німфо» тощо.

Серед кінознавців побутує думка, що вищеперелічені жанри вже давно стали міжнаціональним надбанням і не мають приналежності до окремого кінематографа. Однак запозичені у американців жанри швидко адаптуються до вітчизняних реалій, що надає таким стрічкам певної специфіки. Ці фільми переплітають у собі «чужу» (західну) форму зі «своїм» (вітчизняним) змістом, «своєю» культурою, «своїм» кінематографічним баченням, в результаті чого кожний жанр набуває нового художнього забарвлення. Йдеться про так звану динаміку жанрів, котра сприяє утворенню нових жанрів та жанрової системи. На думку Г. Трепакової, у США можуть запозичуватись жанри кіно, зокрема вестерн і мюзикл, однак ідейний їх зміст буде відчутно іншим [4, 14].

Такі запозичення спостерігаються і в сюжетно-композиційному вирішенні сучасних українських фільмів, що можуть проявлятися в наявності та порядку розміщення елементів сюжету, перебігу подій і сюжетних ліній, в ролях героїв картини, в їх діях та вчинках, темпі розвитку дії, фінальних формулах тощо. Сюжет таких стрічок побудований з точки зору головної вимоги - видовищності. Така ситуація спостерігається у вітчизняних хорорах, трилерах, бойовиках та кримінальних фільмах, в яких можна впізнати класичні сюжетні лінії американських стрічок, котрі розповідають чи то дуже схожу на тарантінівську кримінальну історію про друзів, які втратили гроші і які намагаються виплутатися 3 перипетій («Найбільший теніс» Клима Козинського»), чи то історію бізнесмена, який, розшукуючи свою дружину, поринає у напружений перебіг подій («Таємничий острів» Володимира Тихого), Це, на думку кінокритиків, нагадує фабулу «Гри» Девіда Фінчера або ж комедію «\#SelfieParty» Левицького, сюжет якої нагадує історію зі стрічки «Проект Х: Дорватися» Німи Нурізаде тощо.

Так, стрічки «Штольня» та «Тіні незабутих предків: Таємниця мольфара» Любомира Левицького $є$ типовими трилерами, в яких майже на кожному кроці режисери використовують саспенси. Показовими $\epsilon$ епізоди, коли людина залишається вдома сама й ії починають переслідувати, або коли у важливу мить герої не можуть завести автомобіль тощо. Характерною для американських трилерів $є$ і сцена, яка була показана у «Тінях...», коли герої зупиняються біля придорожньої крамниці, а продавець впізнає на екрані телевізора відвідувачів, котрих розшукують, чи використання уповільненої зйомки при появі головної героїні-красуні. Сюжетна лінія побудована також на основі голлівудських кінотрадицій, що будуються зазвичай на почерговому зниканні або смерті героїв другого плану. Головний герой у «Тінях...» (Дмитро Ступка) завдяки своїй самопожертві рятує не лише кохану дівчину, а й увесь народ. Залишається наприкінці фільму й актор другого плану, який виконував у стрічці роль веселуна (Павло Лі).

Можна навести інший приклад: у стрічці $\epsilon_{B}$ гена Матвієнка «Одинокий за контрактом» показане притаманне американським фільмам гіперболізоване значення зірки естради. Типовим для голлівудських фільмів $є$ момент, коли головний герой (популярний співак), котрому набридає неймовірна слава, йде у народ спробувати простого життя.

Багато хто з сучасних українських режисерів звертався до голлівудських кінематографічних традицій у пошуках ідей, новітніх розробок, отримання досвіду у створенні фільмів, проходид навчання та стажування в Штатах, а також відвідував майстер-класи голлівудських кіновиробників, що 
не могло не позначитися на створеній вітчизняними митцями кінопродукції. Яскравим прикладом $\epsilon$ режисер Любомир Левицький, якого можна назвати чи не найбільшим шанувальником американських кінематографічних надбань серед вітчизняних режисерів, що знайшло своє відображення у його стрічках. Ще на початку своєї творчості кінокритики звинвачували режисера в «голлівудізації» за перенасиченість його картин жанровими штампами і кліше американських фільмів. Як заявив сам Левицький: «Меня обвиняют в том, что я снимаю “американщину”. Может, потому, что я большой фанат Америки» [5].

За останній час в українському кіно відбулися зміни й у системі художніх образів, а разом 3 цим і підборі акторів та характері виконання ними ролей. 3 одного боку, захоплення багатьох вітчизняних акторів голлівудськими зірками не є дивним, враховуючи їхню унікальну майстерність та успішність, згадати лише видатну акторку українського походження Віру Холодну, яка, попри свій успіх, не приховувала свого захоплення американською акторкою Тедою Барою, від якої, на думку кінознавців, і перейняла елементи образу та манеру гри. 3 іншого боку, враховуючи глядацькі вподобання, вітчизняні продюсери та режисери намагаються підібрати типажі акторів, котрі $\epsilon$ звичними і цікавими для українського глядача, який за довгі роки звик до голлівудських фільмів. Також в українських фільмах іноді можна побачити запрошених американських акторів, прикладом чого можна назвати фільми «Аврора» Оксани Байрак та «Сафо» Роберта Кромбі.

Американські кіновиробничі традиції вплинули і на трансформацію знімального персоналу українських фільмів. Спеціалісти кінематографічних галузей були вимушені підлаштовуватись під нові реалії, які диктуються глобалізаційними віяннями та розвитком інформаційних технологій. Так, сьогодні вже не є новою посада продюсера чи супервайзера візуальних ефектів, запозичених у Голлівуду.

Значна кількість запозичень від американських стрічок простежується в площині художнього вирішення, декорацій, одягу, що використовуються у вітчизняних стрічках. Проведення стрітрейсінгу, велика кількість скейтбордистів на вулицях, графіті на стінах та парканах, типове для американських фільмів прибуття «швидкої допомоги», лікарі якої мають нестандартний для України спецодяг, навчальні заходи, стилізовані під американські кампуси, специфіка проведення лекцій у навчальних закладах, де студенти сидять окремо за партами та пишуть олівцями, а не ручками, постійне мерехтіння в кадрі доларів, смартфонів «іPhone» та планшетів «іPad», одяг американського стилю 3 написами англійською тощо - все це є прикладами використання в сучасних українських фільмах американських елементів кіновиробництва і культури в цілому.

Те ж саме можна сказати і про монтаж, комп'ютерну графіку і візуальні ефекти, що їх запропонував Голлівуд не лише вітчизняним кіновиробникам, а й усьому світові. Так, у фільмі «F63.9 Хвороба кохання» Дмитра Томашпольського фантастичні космічні технології показані завдяки комп’ютерній графіці, у фільмі «Найбільший теніс» використовується мальована під комікс графіка, ефект «американська ніч», а також американський, або паралельний, монтаж. Досить часто у створенні фільмів застосовується операторська техніка та комп'ютерні програми, якими користуються голлівудські спеціалісти.

Розглядаючи економічну складову української кіногалузі, можна побачити, як вона змінилась 3 переорієнтацією українського суспільства та економіки на капіталістичний лад. 3'явилася можливість створювати фільми не лише за держзамовленням та для естетичної потреби, а й для отримання від цього прибутку шляхом продажу. Виробнича, маркетингова, системи промоушену і дистриб'юції українських комерційних фільмів мають багато спільного із голлівудськими (хоча 3 перебігом часу вони стають загальноприйнятними серед багатьох країн як новий виток глобалізаційних проявів). Сьогодні українські режисери та продюсери намагаються виводити вітчизняні фільми на міжнародний рівень, вкладаючи великі кошти та адаптуючи стрічки під звиклих до голлівудських тенденцій глядачів.

Також, окрім кінематографічних здобутків, в українських фільмах доволі часто використовуються елементи американської культури і американського способу життя. В деяких фільмах Сполучені Штати згадуються лише опосередковано. Так, у стрічці Роберта Кромбі «Сафо» головними героями виступають американські актори, а герої, яких вони грають, за сюжетом прибули зі США. Вони привнесли ідеали, притаманні американському суспільству: пропагування свободи, демократизму, індивідуалізму, емансипації жінки тощо.

У короткометражному фільмі Анастасії Касілової «Останній день» Сполучені Штати стають головною темою сюжету, де розказується про останній день українського підлітка, який має пере- 
їжджати до Америки, котра видається привабливим і жаданим місцем.

Найбільшого поширення серед усіх елементів американської культури зазнало використання героями у розмові американізмів, на кшталт слів «Wow», «Ok'ey», «Cool», «Super» та інших. Запозичені слова використовуються навіть якщо мова фільму українська. Повальна нині традиція — використання в українських фільмах американської музики та пісень. Цікавим моментом є дубляж українських фільмів українською мовою, до якого вдався Любомир Левицький. Завдяки такому прийому режисер вводить в оману українських глядачів, які підсвідомо ідентифікують фільм як зарубіжний.

Звісно, такі перетини українських і американських здобутків у галузі кіно неоднобічні, проте значно менше кінематографічних або культурних надбань отримують Сполучені Штати 3 українського боку. Причиною цього $\epsilon$, певно, прагнення американських кіновиробників до універсальності, а українське кіно і українська культура мають свої особливості.

Наступною точкою перетину українських i американських відносин у кінематографії $€$ копродукція. Проте практика тут свідчить про не надто активне співробітництво. Це може бути викликано різними причинами: і фінансовою неконкурентоспроможністю України по відношенню до Сполучених Штатів, і територіальна віддаленість країн, і відсутність потрібної законодавчої бази для реалізації проектів (до речі, українські пейзажі могли потрапити в культовий фільм «Список Шиндлера» Стівена Спілберга, проте львівська влада не надала дозвіл). Сполучені Штати більш зацікавлені у фінансуванні української документалістики, аніж українського ігрового кіно.

Україна має унікальні локації для зйомок у деяких американських фільмах були представлені пейзажі та архітектурні споруди великих українських міст, проте через складність зйомок кадри цих пейзажів були взяті з архівних відеоматеріалів або зроблені за допомогою комп'ютерної графіки. Хоча, скажімо, в Одесі проходили зйомки культового бойовика «Перевізник-3» Олів'є Мегатона. У кадр потрапили морське узбережжя Одеси, міські вулиці і базар на Молдаванці. А мешканці міста змогли взяти участь у фільмі як масовка.

Іншим фільмом, у роботі над яким, окрім ще п'ятьох країн, перетнулися американські й українські митці, став «Вій» Олега Степченка. Зйомки відкритих локацій проводилися на території України за участю українських акторів, а американські продюсери і дистриб' ютори опікувалися фінансовими питаннями.

Ще одна співпраця українських і американських кіновиробників має показати результат найближчим часом - це фільм «Солодка Даруся» Олександра Денисенка за підтримки голлівудського кінооператора і режисера Славомира Іздряка.

Однією з форм взаємовідносин у кінематографічній галузі між Україною та Сполученими Штатами $є$ проведення щорічного фестивалю американського кіно «Незалежність» 3 ініціативи Посольства США в Києві з листопада 2011 року. Фестиваль поєднує незалежні американські художні та документальні фільми, які розповідають українській аудиторії про історію Америки і висвітлюють ії розмаїття, і які поза фестом навряд чи були б показані в Україні. «Незалежність» сприяє залученню фахівців американської кіноіндустрії в Україну, заохочуванню взаємозв'язків між українськими та американськими професійними кінематографістами [6].

Таким чином, виходячи з вищесказаного, можна зробити висновок, що українсько-американські відносини в галузі кіно продовжують розвиватися в активному напрямку. Проте спостерігається тенденція запозичень вітчизняними кінематографістами досвіду та набутків у голлівудських колег та рівняння на ветерана кіноіндустрії. Причиною таких запозичень можна назвати безперечну популярність голлівудських фільмів та попит серед глядачів не лише в Україні, а й в усьому світі, які обумовлені високою якістю видовищно-технічного боку кіновиробництва.

Наслідки такого перейняття досвіду є неоднозначними і мають дискусійний характер. Можна навести слова українського дослідника і кінорежисера В. В. Ілляшенка, який зауважує, що, з одного боку, глядач познайомився зі світом і побачив рівень іншої культури, а кіновиробники отримали можливість перейняти досвід у справжніх професіоналів та придбати обладнання високої якості. 3 іншого ж, на думку Ілляшенка, - окремі прояви американського духу чужі Україні, а жорстокість, насильство, сексуальна відвертість, розбещеність, вульгарність, що ними наповнені американські стрічки, - не на користь збагачення українського духовного ринку [7]. У більшості випадків дослідники вбачають у цьому проблему для українського кінематографа, яка може призвести до певної трансформації вітчизняного кіно, віддаляючи його від національних традицій.

Однак було б абсолютно безглуздо протистояти будь-якій появі американського кіно або його 
елементів на наших екранах. Воно потрібне вже 3 міркувань збагачення кінорепертуару на основі взаємодоповнюваності національних культур. Голлівуд може похизуватися височенним рівнем техніки кіно, виконавчим мистецтвом акторів, режисурою і взагалі усім тим, що стосується технології виготовлення фільмів. Для українських кіномитців це - чудова можливість навчитися або перейняти досвід для створення власного якісного продукту і забезпечити кіновиробникам достойну касовість.

Жанрове кіно, безумовно, потрібне Україні, але слід розуміти, що це не набір формальних $\mathrm{i}$ стандартних схем, запозичених у іншої кінематографії. Схеми і кліше українському кінематографові, якщо і потрібні, то власні. Їх слід створювати, адже в голлівудському кіно над ними теж працювали і вони не виникли самі собою. Звісно, після десятирічного простою в нас почали знімати фільми за голлівудською моделлю, але без нехтування місцевими особливостями. Американське кіно в цьому сенсі поставило в Україні якусь планку, задало певний формат. Тому при правильному поєднанні американської видовищності у кіно та глибині поетичного українського кінематографа можна створити справді якісний та цікавий продукт.

\section{Джерела та література}

Вся кинематография. Настольная адресная и справочная книга / под ред. Ц. Ю. Сулиминскаго. - М. : Ж. Чебраріо де Годэнъ, 1916. - 374.

Антонова И. А. Российско-американские отношения в сфере кино в годы второй мировой войны и в первые послевоенные годы [Электронный ресурс] / И. А. Антонова. - Текст. и граф. данные. - Режим доступа: http://naukarus.com/rossiysko-amerikanskieotnosheniya-v-sfere-kino-v-gody-vtoroy-mirovoy-voynyi-v-pervye-poslevoennye-gody

Трепакова А. В. Ценности американского кино. Жанры, образы, идеи : книга для чтения по курсу «Культурология» / А. В. Трепакова. - М. : КДУ, 2007. $-112 \mathrm{c}$.

Юдов М.О. Синкретизм продюсерства і сучасний вітчизняний ринок кіномистецтва / М. О. Юдов // Мистецтвознавчі зап. : зб. наук. пр. / ДАКККіМ. — К., 2009. - Вип. 15. - С. 92.

Онлайн-конференция: задай вопрос известному режиссеру! [Электронный ресурс]// Комсомольська правда в Україні. - Текст. и граф. данные. - Режим доступа: http://kp.ua/press/5607onlain-konferentsyia-zadai-vopros-yzvestnomurezhysseru-vydeo\#sort $=$ new\& $\mathrm{p}=1$

Про фестиваль [Електронний ресурс] // офіційний сайт фестивалю «AIFF». Електрон. дані. - Режим доступу: http://aiffua.com/about/festival-goals/

Ілляшенко В. Історія українського кіномистецтва / В. Ілляшенко. — Київ : Вид-во «ВІК», 2004. — 412 с. 